Kinestetik : Jurnal Ilmiah Pendidikan Jasmani 5 (2) (2021)

Kinestetik : Jurnal Ilmiah Pendidikan Jasmani

https://ejournal.unib.ac.id/index.php/kinestetik/index

DOI : 10.33369/jk.v5i2.17787

\title{
EFFORT TO INCREASE INTEREST AND LEARNING OUTCOME OF DISC THROWING BY USING MELAMINE PLATE MEDIA
}

Yarmani*1, Yahya Eko Nopiyanto $^{2}$, Habib Noprizal ${ }^{3}$

${ }^{123}$ Physical Education, Bengkulu University, Bengkulu City, Indonesia.

\section{Article Info}

Received :June 2021

Revised : June 2021

Accepted : June 2021

Available online: June

2021

\section{Keywords:}

Throw Discs, Melamine Plates, CAR, Learning

Outcomes and Interests.

\begin{abstract}
Efforts to Increase Interest and Learning Outcomes of Throwing Discs Using Melamine Plate Media for Class VIII Students of SMP Negeri 11 Bengkulu Tengah. This study aims to improve the teaching and learning process at SMPN 11 Bengkulu Tengah. CAR was carried out in class VIII.C students, totaling 23 students, consisting of 10 female students and 13 male students. Data collection in this activity was carried out by means of observation sheets, questionnaires and instruments for assessing student movement skills. Observations of teacher and student activities were carried out by two partner teachers in each cycle. Assessment of student movement skills is carried out in each cycle. The results showed that the learning outcomes of students throwing discs using plastic plate media could improve student learning outcomes with learning completeness in cycle I $43 \%$ and cycle II $83 \%$. Learning to throw discs using melamine plate media also increases students' interest in learning as shown from the results of the questionnaire, namely from $83 \%$ in cycle one to $100 \%$ in cycle two which responds positively to learning to throw discs using melamine plate medi
\end{abstract}

Suitable address: Jl. Raden Fatah No.35 Kota Bengkulu

Corresponding email: yarmani@unib.ac.id
ISSN 2685-6514 (Online)

ISSN 2477-331X (Print) 


\section{INTRODUCTION}

Based on the results of observations made by researchers, it is known that there is a lack of infrastructure for learning Discus Throwing at SMPN 11 Central Bengkulu. The school with class VIII consists of 3 classes with an average of 22 students per class, making the Discus Throwing lesson take a long time to complete learning for all VII graders. There are only 2 discs available, which makes discus throwing materials at the same time lacking. So that discus throwing learning becomes ineffective and as a result that the curriculum target is very low.

The shortage of this media has been going on for a long time, and disc facilities have not been fulfilled until now, so that the discs are adequate or in ideal conditions, for example a 1:4 ratio (1 disc for 4 students) based on observations with PJOK teachers at SMPN 11 Bengkulu Tengah.

Discus throwing is an athletic sport that uses a wooden object in the form of a plate with an iron belt, or other flat, round material that is thrown (Andriyani, et al. 2014). So because disc media are basically made of iron, the price of disc media is expensive, while other schools need more. So the researchers tried to modify the disc media using a thick, round and flat Melamine plate. Because Melamine plates are easy to get, cheap and not easily broken and safe for students and not easily broken.

Based on the problems mentioned above, the authors want to apply a media approach in the learning process of discus throwing. Melamine plates will be used as an approach medium in increasing interest and learning outcomes of discus throwing in class VIII SMPN 11 Bengkulu Tengah. The improvement of discus throwing learning outcomes is about: increasing students' seriousness in participating in the discus throwing learning process (increasing student interest and participation in the learning process) and increasing student learning outcomes through student performance in performing discus throwing tests. Based on these problems, the problem in this study is the Efforts to Increase Interest and Learning Outcomes of Discus Throwing Using Melamine Plate Media in Class VIII Students of SMP Negeri 11 Bengkulu Tengah.

\section{METHODS}

The type of research used in this research is Classroom Action Research (CAR). The research subjects were students of class VIII C of State Junior High School 11 Bengkulu Tengah, totaling 23 people consisting of 10 boys and 13 girls.

\section{Sampling Procedure}

The data collection technique consisted of: Test technique, in the form of an action test, namely a motor performance test of students in throwing discs with a modified approach to melamine plate media which includes: the preparation stage, the movement stage, and the final stage of the movement in the form of an assessment sheet and non-test technique, in the form of observing the seriousness of learning which includes: student participation during the learning process and students filling out questionnaires showing students' interest in learning.

The research instrument was a student interest questionnaire in the learning process of discus throwing using the melanin plate media and the discus throwing learning assessment sheet using the modified melanin plate media. It is an instrument to see student learning outcomes, using a modified melanin plate media. The assessment sheet serves to see 
the final results of the learning process and the development of students towards learning to throw discs using modified plastic plate media.

The data obtained from the results of the assessment sheet and the results of the questionnaire will be analyzed descriptively, namely the data findings are described in the form of sentences or statements.

\section{Materials and Equipment}

In the research, efforts to increase interest and learning outcomes of discus throwing using melamine plate media, the materials and equipment used are disc media made using melamine plates. In this study, researchers used melamine plates with a diameter of about 15 to $20 \mathrm{~mm}$ with a thickness of $\pm 10 \mathrm{~mm}$.

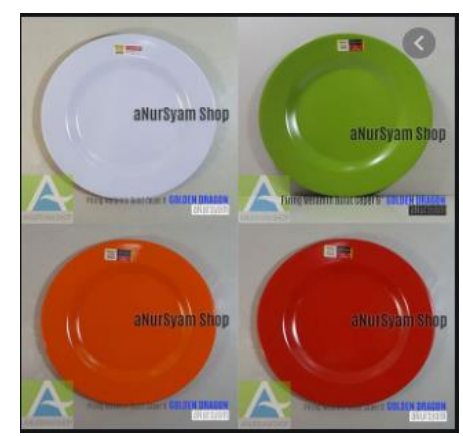

Figure 1. Melamine Plate (Anursyam.shop.2019)

\section{Procedure}

This classroom action research procedure will be carried out in 2 cycles. Each cycle is carried out in accordance with changes in learning outcomes that are desired and achieved based on the factors studied. The material to be studied is discus throwing. Learn to throw discus using melamine plate media. The stages in this Classroom Action Research include planning, Action, Observation, and Reflection.

\section{Data Design or Analysis}

The data obtained from the results of the assessment sheet and the results of the questionnaire will be analyzed descriptively, namely the data findings are described in the form of sentences or statements.

1. Questionnaire data

The criteria for data taken through a questionnaire are data related to students' interest in learning to throw discs using melamine plates.

2. Assessment sheet result data

Based on the minimum completeness criteria (KKM) at SMPN 11

Central Bengkulu, PJOK subjects are declared complete if they meet KKM 75. Then the discus throwing assessment criteria are as follows:

Table 1. Discrimination Throwing Criteria

\begin{tabular}{ccc}
\hline $\begin{array}{c}\text { Assessment } \\
\text { criteria }\end{array}$ & Completeness & Information \\
\hline $\mathbf{9 3}$ & Very good & $\begin{array}{c}\text { Completed } \\
\text { (T) }\end{array}$ \\
\hline $84-92$ & Well & $\begin{array}{c}\text { Completed } \\
(\mathrm{T})\end{array}$ \\
\hline $75-83$ & Enough & Completed (T) \\
\hline $38-74$ & Not enough & $\begin{array}{c}\text { Unfinished } \\
(\mathrm{BT})\end{array}$ \\
\hline $0-37$ & Very less & $\begin{array}{c}\text { Unfinished } \\
(\mathrm{BT})\end{array}$ \\
\hline
\end{tabular}

\section{RESULTS}

\section{Precycle}

Before the implementation in cycle 1 , the researcher took the initial test of discus throwing before being given learning about throwing skills disc. With the initial test, it can be seen the ability of students to do the correct discus throwing 
in accordance with the rules of the discus throwing motion. Initial data was obtained from a pre-cycle test which will be held on July 20, 2020, which will be attended by 23 students of class VIII.C of SMPN 11 Central Bengkulu. The acquisition of the level of Disc Throwing Movement Skills Using Melamine Plate Media can be seen as follows:

Table 2. Pre-cycle Disc Throw Test Results

\begin{tabular}{l|c|l|c}
\hline Amount & 604 & $\begin{array}{l}\text { Number of } \\
\text { Exam } \\
\text { Participants }\end{array}$ & 23 people \\
\hline Average & 26 & $\begin{array}{l}\text { Completed } \\
\text { Amount }\end{array}$ & 0 people \\
\hline $\begin{array}{l}\text { The highest } \\
\text { score }\end{array}$ & 56 & $\begin{array}{l}\text { Unfinished } \\
\text { Amount }\end{array}$ & 23 people \\
\hline $\begin{array}{l}\text { Lowest } \\
\text { Value }\end{array}$ & 16 & $\begin{array}{l}\text { Above } \\
\text { average }\end{array}$ & 10 people \\
\hline $\begin{array}{l}\text { Learning } \\
\text { skills }\end{array}$ & $0 \%$ & $\begin{array}{l}\text { Below } \\
\text { average }\end{array}$ & 13 people \\
\hline
\end{tabular}

Based on the results of the initial test, the tablethe it is shown that the percentage of completeness is still $0 \%$ with the average grade value of 23 students is 26 .

Based on the initial test data which was still very low, the researcher collaborated with colleagues and PJOK teachers at SMPN 11 Bengkulu Tengah, to improve students' ability to throw discus. So that The researcher will apply discus throwing learning using melamine plate media for class VIII.C students of SMPN 11 Bengkulu Tengah.

\section{Cycle 1}

Discus throwing lessons in cycle 1 were held on Monday 27 July 2020 at 08.00 to 09.45 at the soccer field of SMPN 11 Central Bengkulu. At the first meeting of cycle 1 , the researcherasThe teacher will give a side style discus throwing lesson. The second meeting was held on Thursday 30 July 2020 at 08.00 to 09.45 , researchers evaluated students' movement skills using a discus throwing motion assessment instrument using melamine plate media.

After students take part in the learning process, students are given another questionnaire to find out the student's response to the process learningwhich has taken place. Students' learning interest in learning to throw discs using melamine plate media can be seen from the results of student questionnaires.

Table 3. Results of Cycle 1Questionnaire

\begin{tabular}{l|c|l|c}
\hline Amount & 191 & $\begin{array}{l}\text { Number of } \\
\text { Exam } \\
\text { Participants }\end{array}$ & 23 people \\
\hline Average & 8 & $\begin{array}{l}\text { Number of } \\
\text { Positive } \\
\text { Responses }\end{array}$ & 19 people \\
\hline $\begin{array}{l}\text { The } \\
\text { highest } \\
\text { score }\end{array}$ & 10 & $\begin{array}{l}\text { Number of } \\
\text { Negative } \\
\text { Responses }\end{array}$ & 4 people \\
\hline $\begin{array}{l}\text { Lowest } \\
\text { Value }\end{array}$ & 5 & $\begin{array}{l}\text { Above } \\
\text { average }\end{array}$ & 13 people \\
\hline $\begin{array}{l}\text { Learning } \\
\text { skills }\end{array}$ & $83 \%$ & $\begin{array}{l}\text { Below } \\
\text { average }\end{array}$ & 10 people \\
\hline
\end{tabular}

Based on table 3, the analysis of the results of the first cycle of the questionnaire which was followed by 23 students obtained the percentage of students who had a positive response to learning to throw. disc19 people using melamine plate media or $83 \%$. This means that students' interest in learning takes part in learning to throw discs using melamine plate media so that it can be concluded that students respond positively.

After learning cycle 1 is complete, student learning outcomes are obtained based on charging the teacher uses the instrument sheet for the assessment of discus throwing motion skills using melamine plate media, which can be seen in the table below: 
Table 4. Test Results of Cycle 1 Throwing

\begin{tabular}{lclc} 
& \multicolumn{3}{l}{ Discs } \\
\hline Amount & 1.480 & $\begin{array}{l}\text { Number of } \\
\text { Exam } \\
\text { Participants }\end{array}$ & 23 people \\
\hline Average & 64 & $\begin{array}{l}\text { Completed } \\
\text { Amount }\end{array}$ & 10 people \\
\hline $\begin{array}{l}\text { The } \\
\text { highest } \\
\text { score }\end{array}$ & 80 & $\begin{array}{l}\text { Unfinished } \\
\text { Amount }\end{array}$ & 13 people \\
$\begin{array}{l}\text { Lowest } \\
\text { Value }\end{array}$ & 48 & $\begin{array}{l}\text { Above } \\
\text { average }\end{array}$ & 10 people \\
\hline $\begin{array}{l}\text { Learning } \\
\text { skills }\end{array}$ & $43 \%$ & $\begin{array}{l}\text { Below } \\
\text { average }\end{array}$ & 13 people \\
\hline & & &
\end{tabular}

From results cycle 1 test carried out, which followed by 23 students, 10 students got scores above the KKM, which is 75 . Which means that student learning completeness is $43 \%$ with a class average of 64 . But learning mastery has not been fulfilled classically so it must be continued in cycle 2 .

In particular assessment of discus throwing skills using media melamine plate with the number of participants 23 students according to the aspects assessed can be seen in table 5 below

Table 5. Assessment of Disc Throwing Motion Skills Using Melamine Plate Media Cycle 1

\begin{tabular}{llc}
\hline No & \multicolumn{1}{c}{ Rated aspect } & $\begin{array}{c}\text { Completeness } \\
\text { Presentation }\end{array}$ \\
\hline 1 & Starting Position (N1) & $99 \%$ \\
\hline 2 & Prefix Motion (N2) & $72 \%$ \\
\hline 3 & $\begin{array}{l}\text { Twisting Movement } \\
(\mathrm{N} 3)\end{array}$ & $65 \%$ \\
\hline 4 & Power Position (N4) & $43 \%$ \\
\hline 5 & Release Motion (N5) & $43 \%$ \\
\hline
\end{tabular}

From the data in table 5 , it can be seen that the aspects assessed in discus throwing skills usingplate melamine mastery percentage is less than $75 \%$ seen in the aspect of the prefix still72\%, 65\% twisting motion, $43 \%$ power position and $43 \%$ release motion. So from the results of the assessment of these aspects, the researchers should put more emphasis on learning the prefix motion, twisting motion, power position and correct release motion according to the criteria for assessing each aspect. The researcher will collaborate with colleagues and PJOK teachers at SMPN 11 Bengkulu Tengah, to improve and enhance students' ability to throw discus. So that researchers will apply learning to throw discs using melamine plate media for class VIII.C students of SMPN 11 Bengkulu Tengah, continued in the second cycle.

\section{Cycle Data 2}

Discus throwing lessons in cycle 2 were held on Monday, August 10, 2020 at 08.00 to 09.45 at the soccer field of SMPN 11 Bengkulu Tengah. At this second cycle meeting, the researcher as a teacher will provide discus throwing lessons. The second meeting was held on Thursday, August 13, 2020 at 08.00 to 09.45, the researchers evaluated the students' back style discus throwing motion skills using the discus throwing motion assessment instrument using melamine plate media.

Table 6. Results of Cycle 2 . Questionnaire

\begin{tabular}{lclc}
\hline Amount & 208 & $\begin{array}{l}\text { Number of } \\
\text { Exam } \\
\text { Participants }\end{array}$ & 23 people \\
\hline Average & 9 & $\begin{array}{l}\text { Number of } \\
\text { Positive } \\
\text { Responses }\end{array}$ & 23 people \\
\hline $\begin{array}{l}\text { The } \\
\text { highest } \\
\text { score }\end{array}$ & 10 & $\begin{array}{l}\text { Number of } \\
\text { Negative } \\
\text { Responses }\end{array}$ & 0 people \\
\hline $\begin{array}{l}\text { Lowest } \\
\text { Value }\end{array}$ & 8 & $\begin{array}{l}\text { Above } \\
\text { average }\end{array}$ & 8 people \\
\hline $\begin{array}{l}\text { Learning } \\
\text { skills }\end{array}$ & $100 \%$ & $\begin{array}{l}\text { Below } \\
\text { average }\end{array}$ & 15 people \\
\hline
\end{tabular}

Based on table 6 the analysis of the results of the questionnaire is obtained percentage 23 students who have a positive response to learning to throw discs using melamine plate media 
or $100 \%$ in cycle 2 . This means that students' learning interest in learning to throw discs using melamine plate media can be concluded that students respond positively.

After learning cycle 2 is complete, student learning outcomes are obtained based on teacher filling using an instrument sheet for assessing discthrowing motion skills using melamine plate media, which can be seen in the table below:

Table 7. Test Results of Cycle 2 Throwing

\begin{tabular}{lcll}
\multicolumn{4}{c}{ Discs } \\
\hline Amount & $\begin{array}{c}1.85 \\
6\end{array}$ & $\begin{array}{l}\text { Number of } \\
\text { Exam } \\
\text { Participants }\end{array}$ & 23 person \\
\hline Average & 81 & $\begin{array}{l}\text { Completed } \\
\text { Amount }\end{array}$ & 19 person \\
\hline $\begin{array}{l}\text { The } \\
\text { highest } \\
\text { score }\end{array}$ & 96 & $\begin{array}{l}\text { Unfinished } \\
\text { Amount }\end{array}$ & 4 person \\
\hline $\begin{array}{l}\text { Lowest } \\
\text { Value }\end{array}$ & 48 & $\begin{array}{l}\text { Above } \\
\text { average }\end{array}$ & 14 person \\
\hline $\begin{array}{l}\text { Learning } \\
\text { skills }\end{array}$ & $83 \%$ & $\begin{array}{l}\text { Below } \\
\text { average }\end{array}$ & 9 person \\
\hline
\end{tabular}

From results the 2nd cycle test that was carried out, showed that it was partially studentwho knows good and correct discus throwing techniques. It can be seen from the students' learning completeness of $83 \%$ with an average value of 81 .

In particular Discus throwing skills assessment use melamine plate media with the number of participants 23 students according to the aspects assessed can be seen in table 8 below

Table 8. Assessment of Disc Throwing Motion Skills Using Melamine Plate Media Cycle 1

\begin{tabular}{clc}
\hline No & Rated aspect & $\begin{array}{c}\text { Completeness } \\
\text { Presentation }\end{array}$ \\
\hline 1 & $\begin{array}{l}\text { Starting Position } \\
\text { (N1) }\end{array}$ & $99 \%$ \\
\hline 2 & Prefix Motion (N2) & $83 \%$ \\
\hline
\end{tabular}

\begin{tabular}{clc}
\hline 3 & $\begin{array}{l}\text { Twisting } \\
\text { Movement (N3) }\end{array}$ & $75 \%$ \\
\hline 4 & $\begin{array}{l}\text { Power Position } \\
\text { (N4) }\end{array}$ & $74 \%$ \\
\hline 5 & $\begin{array}{l}\text { Release Motion } \\
\text { (N5) }\end{array}$ & $72 \%$ \\
\hline
\end{tabular}

FromTable 8 data shows that the aspects assessed in discus throwing skills using a melamine plate in the initial position aspect (N1) $99 \%$ of students have been able to do the initial position well. In the early movement aspect (N2), $83 \%$ of students have done well. In the aspect of circular motion has also been fulfilled by $75 \%$. While in the aspect of power position (N4) $74 \%$ and Release Motion (N5) 72\%. So the aspect in discus throwing motion skills is of good value and student learning completeness in class is $83 \%$, which means that it is more than the minimum completeness requirement of $75 \%$.

So that the learning completeness on the discus throwing material has been completed because it is more than $75 \%$. And learning outcomes have increased from cycle 1 to cycle 2 , namely from $43 \%$ to $80 \%$.

\section{DISCUSSION}

Based on the results of the data analysis above, it is known that learning to throw discs using melamine plate media can increase student interest and learning outcomes. The results of this study are supported by the results of previous studies which state that the effectiveness of learning to throw discs with plastic plate media has increased (Sujati, 2015). The results of other studies also state that there is an increase in the interest and creativity of students' movements after the action using plastic plate media is carried out (Andriyani, 2014). 
Student interest questionnaires were given during the learning process by learning to throw discs using melamine plate as the media. according to rusmiati(2017) "interest is a feeling that encourages someone to do an activity or the motivation behind someone doing something. Interest in learning is the drive that a person has to carry out learning activities. so that using an interest questionnaire it can be seen how much interest students have in learning to throw discs using melamine plate media.

Based on classroom action research procedures that have been systematically designed and implemented, researchers can collect research data whichmay be important information from research results. Based on the results of the questionnaire in cycle 1 , students' interest in learning was $83 \%$, and in cycle two, student interest in learning increased to $100 \%$, which means that all students of class VIII.C were very interested in participating in discus throwing lessons using melamine plate media. Learning to throw discs using melamine plates for class VIII students at SMPN 11 Bengkulu Tengah gave a positive impact as seen from the student interest questionnaire who responded positively to learning to throw discs. And the process can also be seen based on the observations of fellow researchers and PJOK teachers at SMPN 11 Central Bengkulu.

In addition to knowing students' interest in learning, the researchers also discussed the results of learning to throw discs with melamine plate media using a test Skillsdiscus throwing motion using the discus throwing skill assessment sheet. In the initial test given by the researcher to students who had not been given material and examples of good and correct discus throwing movements, the test results obtained were very low student learning outcomes with $0 \%$ completeness. This is because students are not familiar with the discus throwing technique that is good and correct.

Then in cycle 1 , the researcher gave discus throwing material and gave an example of discus throwing motion to students. Learning outcomes obtainedflatthe average student becomes 64 and the completeness of learning becomes $43 \%$. Of the 23 students, as many as 10 students who have completed and 13 more students who have not, so it will be corrected in the second cycle. Because even though it has increased from the initial test to cycle 1 , it has not reached the Minimum Completeness Criteria (KKM) which is 75 in PJOK subjects at SMPN 11 Central Bengkulu.

After being re-explained and demonstrated by the researcher in cycle 1 , the results of good and correct discus throwing according to the discus throwing assessment criteria increased from the cycle 1 test to cycle 2 . The average score of students from 64 to 81 , and their learning completeness increased from $43 \%$ to $83 \%$, so from the test results in cycle 2 that have reached the KKM as much as $83 \%$. So according to the classical learning completeness criteria, the discus throwing learning objectives have been achieved. With the increase in student learning outcomes in cycle 2 , so that classroom action research ends in cycle 2 .

Learning outcomes of discus throwing using melamine plates increased learning outcomes seen from the average value of students. This increase in learning outcomes occurs from the learning process from the examples given by the teacher and students' skills in practicing what they have learned. This is in accordance with Suprijono (2012) learning outcomes are patterns of actions, values, 
understandings, attitudes, appreciation and skills.

\section{CONCLUSION}

From the results of research that has done then it can be concluded that the enhancement interest in learning by applying learning to throw disc using melamine plate media, namely during the learning process with learning learning to throw discs using melamine plate media, the interest questionnaire was 23 students or $100 \%$ of students were positive in learning learning to throw discs using melamine plates.

Increased learning outcomes of discus throwing with the implementation of learning learning to throw discs using melamine plate media obtained by students each cycle both in terms of average and complete learning. the average value of students increased from 64 in the first cycle to 81 in the second cycle, and learning completeness rose from $43 \%$ in the first cycle to $83 \%$ in the second cycle.

The writing of this research report can be completed because Allah, SWT has allowed various related parties to help the author. The author respectfully and humbly expresses his gratitude to Mrs. Yarmani as the main supervisor of this research who provided many suggestions, inputs and guidance so that this thesis was completed with patience and sincerity and also Mr. Yahya Eko Nopiyanto as a companion supervisor in this research, who was always sincere. many suggestions and guidance so that the completion of this thesis

\section{REFERENCES}

Andriyani, Yeni et al. (2014). The Implementation of Sideways Style Disc Throwing Learning Using Sitetive Methods in Order to Grow
Interest and Movement Creativity in Class XI Accounting 1 SMK Negeri 1 Nanga Pinoh. Journal of Physical Education Health and Recreation: 47-56

Anursyam.shop.(2019). 9 Golden Dragon

Flat Melamine Plate.

(https://www.google.com/search?

$\mathrm{q}=$ plate + melamine $\&$ safe $=$ strict $\& \mathrm{t}$ $\mathrm{bm}=\mathrm{isch} \&$ source) accessed March 11,2020

Arikunto, Suharsimi et al. (2007). Classroom action research. Jakarta: Earth Literacy.

Barnawi and Arifin. (2012). Professional Teacher Performance. Jogjakarta: Ar-Ruzz Media Indonesia Journal of Sports and Physical Education | Vol. 1(1): 2019 | 19 |

BSNP. (2006). Sports physical Education and health. Jakarta: Debdikbud.

Education Teacher. (2019). Throw Disc.https://www.guru

Pendidikan.co. id/throw-disc/ accessed April 2, 2020

KBBI

Online.(2019).https://kbbi.kemdik bud.go.id accessed March 11, 2020.

Masturi. (2016). Improved Disc Throwing Ability With Plastic Plate Modification Media. Journal of Character Learning Innovation (JIPK) Vol.1 No.2 December 2016: 1-8.

Nopiyanto, Yahya Eko et al.(2019). Relationship between Leg Length and Explosive Power of Limb Muscles with Sprint Results of 100 Meters. Kinesthetic Journal: Physical Education Scientific Journal, 3(2) 2019: 256-261.

Nopiyanto, Yahya Eko et al (2019). Philosophy of Physical Education and Sports. Bengkulu: Zara Abadi. 
Nopiyanto, Yahya Eko et al (2020). Athletic Learning. Bengkulu: Elmarkazi.

Purnomo, Eddy. (2011). The Fundamentals of Athletic Motion. Yogyakarta: Alfamedia

Sujati, Puji. (2015). Efforts to Improve Disc-Throwing Learning Using Modified Plastic Plate Media for Fifth Grade Students of SD Negeri Klegung 1, Tempel District, Sleman Regency. Yogyakarta: UNY

Suprijono, Agus. (2012). Cooperative Learning: PAIKEM Theory and Application. Yogyakarta: Student Library. 